ISSN 1029-8940 (Print)

ISSN 2524-230X (Online)

УДК 630.430

https://doi.org/10.29235/1029-8940-2018-63-3-316-327

Поступила в редакцию 17.10.2017

Received 17.10.2017

\title{
В. В. Усеня
}

\author{
Институт леса НАН Беларуси, Гомель, Республика Беларусь
}

\section{ПОСЛЕПОЖАРНОЕ СОСТОЯНИЕ И ВОССТАНОВЛЕНИЕ ЛЕСНЫХ ФИТОЦЕНОЗОВ НА ТЕРРИТОРИИ РЕСПУБЛИКИ БЕЛАРУСЬ}

\begin{abstract}
Аннотация. Представлены результаты многолетних стационарных исследований по влиянию пирогенного фактора на продуктивность и послепожарное состояние лесных фитоценозов Беларуси. Установлено, что величина послепожарного отпада деревьев и их радиальный прирост в насаждениях основных лесообразующих пород определяются видом и интенсивностью пожара, лесоводственно-таксационной характеристикой древостоев, а также биологическими особенностями древесных пород. В сосновых, еловых, березовых и черноольховых насаждениях выявлены зависимости величины послепожарного отпада по запасу древесины от их среднего диаметра и средней высоты нагара на стволах при низовых пожарах, глубины прогорания органических горизонтов почвы и степени повреждения корневых систем деревьев при почвенных пожарах. Разработаны шкалы для определения степени повреждения пожарами насаждений основных лесообразующих пород и их пожароустойчивости. Изложены методы лесовосстановления на гарях в различных лесорастительных условиях, обеспечивающие формирование биологически устойчивых и высокопродуктивных насаждений хозяйственно ценных древесных пород. Представлена карта лесопожарного районирования территории Беларуси, на основании которой дифференцированы виды и объемы мероприятий по противопожарному обустройству лесного фонда юридическими лицами, ведущими лесное хозяйство, с целью минимизации площади лесных пожаров и их последствий.

Ключевые слова: лесные фитоценозы, пирогенный фактор, послепожарное состояние, продуктивность, диагностика, шкала, методы лесовосстановления гарей, лесопожарное районирование, минимизация лесных пожаров и их последствий

Для цитирования: Усеня, В. В. Послепожарное состояние и восстановление лесных фитоценозов на территории Республики Беларусь / В. В. Усеня // Вес. Нац. акад. навук Беларусі. Сер. біял. навук. - 2018. - Т. 63, № 3. - С. 316 -327. https://doi.org/10.29235/1029-8940-2018-63-3-316-327
\end{abstract}

\section{V. Usenya}

Forest Institute of the National Academy of Sciences of Belarus, Gomel, Republic of Belarus

\section{POSTFIRE CONDITION AND RENEWAL OF FOREST PHYTOCENOSES ON THE TERRITORY OF THE REPUBLIC OF BELARUS}

\begin{abstract}
Results of long-term stationary research on influence of the pyrogenic factor on the efficiency and the postfire condition of forest phytocenoses of Belarus are presented. It has been found out that the size of the postfire falling off of trees and their radial gain in plantations of the main forest forming breeds are determined by the type and intensity of a fire, the forest and taxation characteristics of forest stands as well as biological features of tree species. Dependence of the size of the postfire falling off by the quantity of trees and a stock in pine, spruce, birch and black alder plantations on their average diameter and average height of deposit on trunks are revealed at the ground fires, depths of burn-out of organic horizons of the soil and damage rate of root systems of trees - at the soil fires. The description of scales for identification of damage rate in plantations of the main forest forming breeds from fires and their fire resistance is given. The reforestation methods in the burnt-out places in various forest vegetation conditions which provide formation of biologically steady and highly productive plantations of economic valuable tree species are presented. There is a card of forest fire division into districts of the territory of Belarus on the basis of which types and volumes of actions for fire-prevention arrangement of the forest fund of the legal entities which conduct forestry for the purpose of minimization of the area of wildfires and their consequences are differentiated.

Keywords: forest phytocenoses, pyrogenic factor, postfire state, productivity, diagnostics, scale, methods of reforestation of burnt-out places, forest fire division into districts, minimization of wildfires and their consequences

For citation: Usenya, V. V. Postfire condition and renewal of forest phytocenoses on the territory of the Pepublic of Belarus. Vestsi Natsyyanal'nai akademii navuk Belarusi. Seryya biyalagichnych navuk = Proceedings of the National Academy of Sciences of Belarus. Biological series, 2018, vol. 63, no. 3, pp. 316-327 (in Russian). https://doi.org/10.29235/1029-89402018-63-3-316-327
\end{abstract}

(C) Усеня В. В., 2018 
Введение. Лесистость территории Республики Беларусь составляет 39,8 \%. Леса являются одним из основных возобновляемых природных богатств, важным компонентом экологического каркаса региона. Они не только представляют большую ценность как ресурсы древесины, но и выполняют природоохранные, средообразующие, рекреационно-оздоровительные и иные полезные функции, имеют большое значение для устойчивого социально-экономического развития страны.

В силу своего породного, возрастного и структурного состава и сильного антропогенного воздействия лесные фитоценозы являются потенциально пожароопасными. В видовом составе лесов преобладают (59,4 \%) пожароопасные хвойные породы: сосна обыкновенная (Pinus sylvestris L.) - 50,1 \% и ель европейская (Picea abies (L.) Karst) - 9,3 \% [1].

Из множества природных и антропогенных факторов пожары оказывают доминирующее негативное влияние на продуктивность лесов, качественный состав лесного фонда и динамику восстановления лесных фитоценозов, что снижает биологическую устойчивость последних [2-15].

Под воздействием пирогенного фактора в лесных фитоценозах образуются гари и горельники - площади с полностью или частично погибшим древостоем соответственно. Если в первом случае лесохозяйственные мероприятия сводятся к сплошной рубке утративших жизнеспособность древостоев и последующему проведению лесовосстановления, то в горельниках проведение данных мероприятий является более сложной задачей, требующей максимально достоверной диагностики послепожарного состояния насаждений. Наличие такой диагностики и установление продолжительности послепожарного отпада деревьев в пройденных пожарами древостоях позволяет не только правильно оценить размер причиненного и ожидаемого материального и экологического ущерба, но и своевременно и обоснованно наметить первоочередные мероприятия по снижению негативных последствий пожаров на лесные фитоценозы и лесовосстановлению последних.

Охрана лесов от пожаров и ликвидация их последствий - важнейшие составные части мероприятий по сохранению природного комплекса, обеспечивающие устойчивость лесных экосистем и сохранение биологического разнообразия. В связи с этим в природно-климатических и лесорастительных условиях Беларуси необходимо решение ряда научно-прикладных задач по профилактике лесных пожаров, установлению влияния пирогенного фактора на продуктивность лесных фитоценозов и диагностике их послепожарного состояния, разработке методов лесовосстановления гарей и формированию пожароустойчивых насаждений основных лесообразующих пород.

Цель настоящего исследования - изучение влияния различного вида и интенсивности пожаров на продуктивность и состояние лесных фитоценозов, разработка и научное обоснование методов и шкал оценки послепожарного состояния насаждений основных лесообразующих пород, дифференцированной системы мероприятий по лесовосстановлению гарей и формированию пожароустойчивых лесных формаций.

Объекты и методы исследования. Объектом исследований являлись сосновые, еловые, березовые и черноольховые насаждения в лесном фонде Беларуси после различного вида и интенсивности пожаров.

Многолетнюю динамику пожаров (количество случаев и площадь) устанавливали на основании ежегодных статистических бюллетеней Национального статистического комитета Республики Беларусь «Лесные пожары в Республике Беларусь» в соответствии с формой государственной статистической отчетности 1-ЛХ (пожары) «Отчет о лесных пожарах».

Изучение величины послепожарного отпада в 11-75-летних насаждениях основных лесообразующих пород, подверженных влиянию различного вида и интенсивности пожаров, и установление критериев и показателей степени их повреждения проводили на стационарных и временных пробных площадях (ПП) во всех геоботанических (лесорастительных) подзонах страны [16]: 1) широколиственно-еловых лесах (дубово-темнохвойных) (21 ПП); 2) елово-грабовых дубравах (грабово-дубово-темнохвойных лесах) (48 ПП); 3) грабовых дубравах (широколиственно-сосновых лесах) (59 ПП). Закладка ПП, определение лесоводственно-таксационных характеристик и послепожарного состояния насаждений выполнены в соответствии с общепринятыми в лесоводстве и лесной таксации методическими разработками [17-19]. 
В насаждениях, пройденных низовыми пожарами, замеряли диаметр и высоту нагара на стволе каждого дерева, а в пройденных почвенными пожарами - глубину прогорания органических горизонтов почвы. При почвенных пожарах определяли также степень повреждения (обгорания) корневых систем деревьев. Проводили визуальную оценку жизнеспособности деревьев на пробных площадях, используя шкалу оценки категорий состояния деревьев [20]. По числу деревьев и их запасу в насаждениях устанавливали уровни послепожарного отпада и на основании этого разрабатывали шкалы для определения степени их повреждения низовыми и почвенными пожарами.

Динамику радиального прироста в пройденных пожарами насаждениях изучали путем отбора приростным буравом кернов древесины на высоте 1,3 м у деревьев с различными ступенями толщины и замера их среднепериодического текущего прироста в 5-летний до- и послепожарный периоды при помощи специальной программы (Biokern) обработки изображений прироста кернов на основе алгоритмического анализа полученных результатов.

На основании лесоводственно-таксационной характеристики насаждений, оценки запасов лесных горючих материалов и определения величины послепожарного отпада деревьев о запасу древесины разработана шкала оценки пожароустойчивости насаждений основных лесообразующих пород.

Для лесопожарного районирования территории Беларуси использовали комплексный показатель потенциальной опасности возникновения и распространения лесных пожаров, включающий следующие критерии: класс природной пожарной опасности лесов, лесистость, плотность населения региона, уровень многолетней горимости лесов, закрепление территории лесного фонда по зонам радиоактивного загрязнения за юридическими лицами, ведущими лесное хозяйство. При лесопожарном районировании учитывали взаимосвязь и степень влияния указанных выше критериев на горимость лесов конкретного региона с учетом коэффициента их значимости.

Результаты и их обсуждение. На территории Беларуси на протяжении 1959-2016 гг. возникло 136,1 тыс. пожаров на общей площади 215,2 тыс. га (рис. 1).

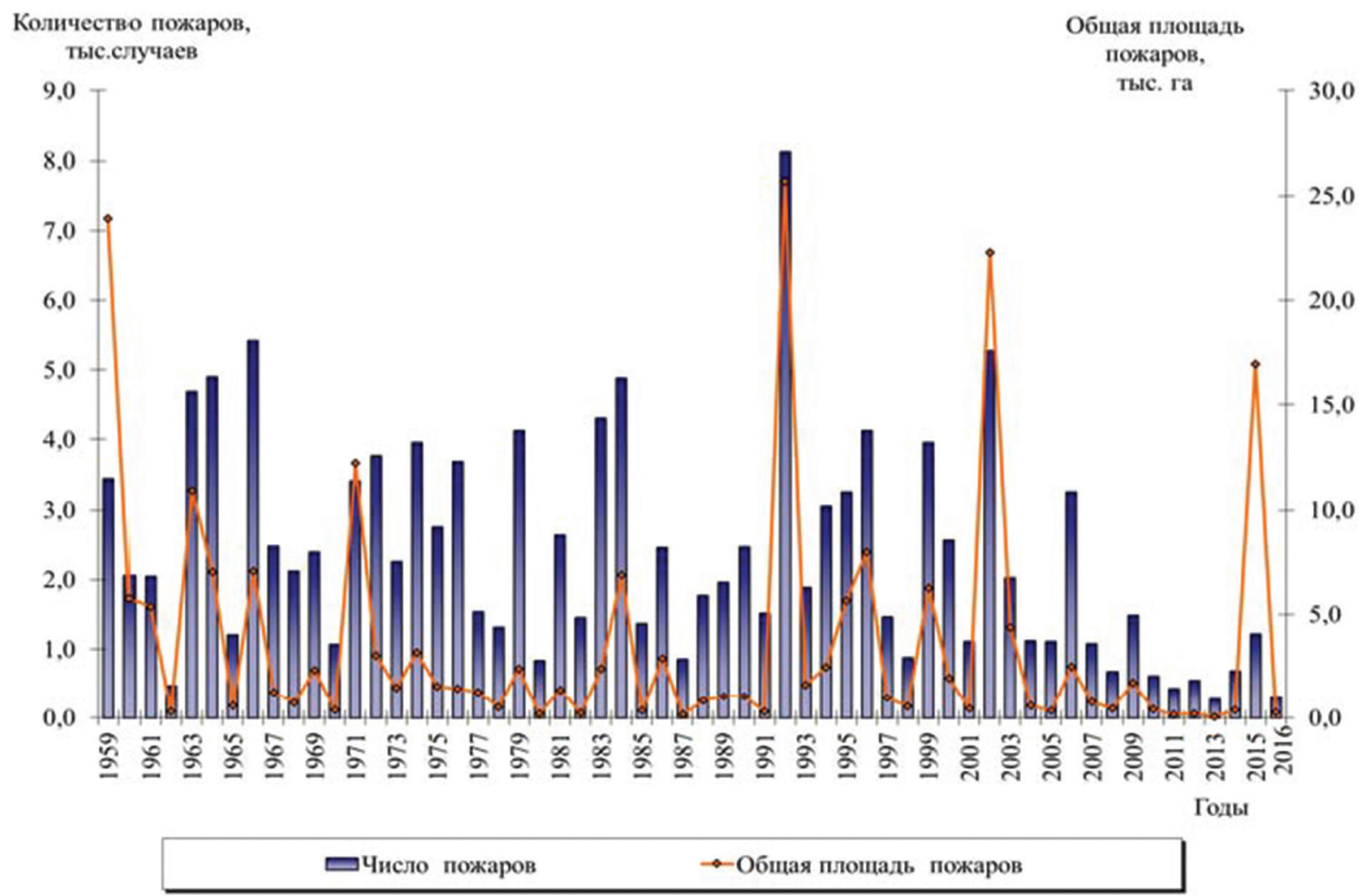

Рис. 1. Динамика пожаров в лесном фонде Беларуси

Fig. 1. Dynamics of fires in the forest fund of Belarus 
Средняя площадь одного пожара составила 1,58 га (минимум - 0,16 га, максимум - 6,93 га). Максимальное количество случаев возникновения пожаров и пройденной ими площади наблюдалось 2-3 раза на протяжении каждого десятилетия. В лесном фонде низовые пожары составили $84,1 \%$, верховые - 12,6 , почвенные - $3,3 \%$ от общей площади возгорания.

Полученные результаты исследований позволили установить количественные показатели послепожарного отпада по числу деревьев и их запасу в подверженных низовым пожарам сосновых, еловых, березовых и черноольховых насаждениях в зависимости от среднего диаметра и средней высоты нагара на стволах. Величина послепожарного отпада определяется видом и интенсивностью пожара, лесоводственно-таксационной характеристикой древостоев, а также биологическими особенностями древесных пород. При низовых пожарах наблюдается прямая зависимость увеличения величины послепожарного отпада деревьев с уменьшением среднего диаметра древостоя и увеличением средней высоты нагара на стволах. Установлено, что при среднем диаметре насаждений ели 6-12 см и средней высоте нагара 1,6-2,0 м отпад по числу деревьев составляет $100 \%$, сосны - 86-100\%. При одинаковой средней высоте нагара на стволах деревьев и среднем диаметре древостоя более значительно повреждаются огнем насаждения ели в силу более низкой пожароустойчивости данной древесной породы. Так, в насаждениях при средней высоте нагара на стволах 2,1-2,5 м послепожарный отпад по числу деревьев со средним диаметром ствола 16-32 см составил: ели - 50-96 \%, сосны - 2-66 \%. В 25-40-летних сосновых насаждениях максимальная величина отпада деревьев наблюдалась в первые два послепожарных года и составляла при низовых пожарах сильной интенсивности (высота нагара $(h)$ на коре стволов 2,1 м и более) $52-74 \%$, средней $(h=1,1-2,0$ м) - 12-15, слабой $(h \leq 1,0$ м) - 3-4 \% от общего запаса древостоев. В 35-55-летних еловых насаждениях максимальная величина послепожарного отпада, вне зависимости от интенсивности пожара, наблюдалась в год пожара и при сильной интенсивности составляла $87-96 \%$, при средней - 56-79, при слабой - 21-23\% от общего запаса древостоя. В последующие три послепожарных года достоверного увеличения величины послепожарного отпада не установлено, т. е. данный показатель в еловых насаждениях практически стабилизируется уже в год пожара.

Множественный регрессионный анализ выявил достоверную зависимость величины послепожарного отпада деревьев по числу стволов от их среднего диаметра и средней высоты нагара, которые и явились определяющими критериями при установлении степени повреждения деревьев хвойных древостоев низовыми пожарами (рис. 2).

Полученные закономерности послепожарного отпада деревьев основных лесообразующих пород, поврежденных низовыми пожарами, свидетельствуют о том, что жизнеспособность деревьев определяется диаметром их ствола и высотой нагара (табл. 1).

В зависимости от величины послепожарного отпада выделены четыре степени повреждения насаждений верховыми и низовыми пожарами, которые являются основным критерием для оценки состояния этих насаждений с целью проведения необходимых мероприятий по повышению продуктивности древостоя и ликвидации последствий пожаров:

I - слабая степень повреждения. После низового пожара слабой интенсивности повреждения деревьев верхнего полога незначительны. Подчиненный полог древостоя или частично отмирает, или полностью сохраняет жизнеспособность, отпад по числу деревьев не превышает 15 \%, по запасу $-10 \%$.

II - средняя степень повреждения. После низового пожара слабой и средней интенсивности большинство деревьев верхнего полога сохраняет жизнеспособность, подчиненный полог древостоя погибает полностью, отпад по числу деревьев составляет 16-30 \%, по запасу - 11-25 \%.

III - сильная степень повреждения. После низового пожара средней интенсивности значительная часть древостоя верхнего полога еще сохраняет жизнеспособность, отпад по числу деревьев составляет 31-50 \%, по запасу - 26-50\%.

IV - очень сильная степень повреждения. После верхового или низового пожара сильной интенсивности древостой полностью утрачивает жизнеспособность, отпад превышает 50 \% от общего числа деревьев и их запаса. 


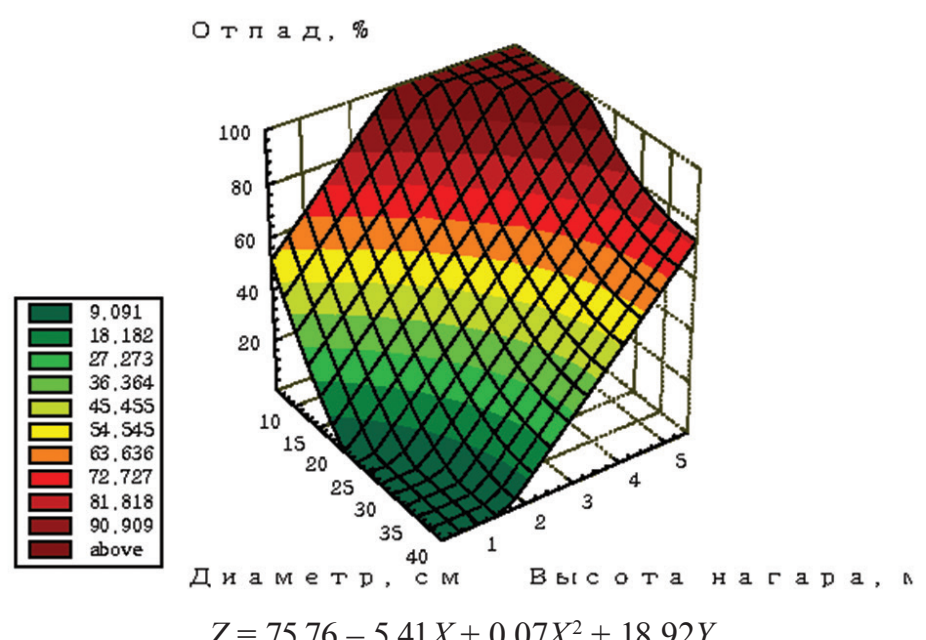

$Z=75,76-5,41 X+0,07 X^{2}+18,92 Y$

Сосна

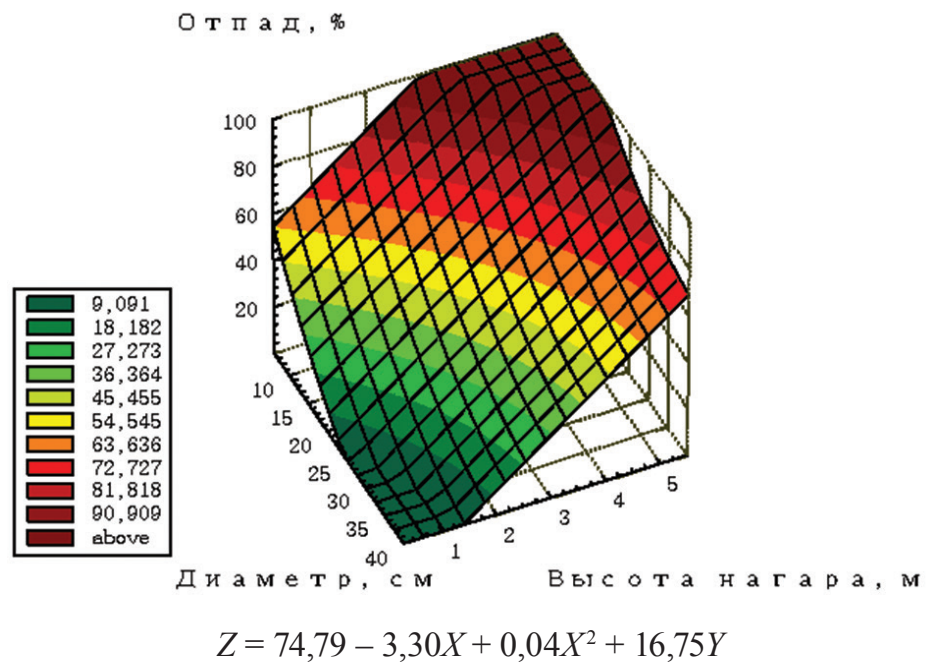

Ель

Рис. 2. Зависимость послепожарного отпада $(Z)$ деревьев в хвойных насаждениях от их среднего диаметра $(X)$ и средней высоты нагара на стволах $(Y)$

Fig. 2. Dependence of postfire falling off $(Z)$ of trees in coniferous plantations on their average diameter $(X)$ and average height of deposit on trunks $(Y)$

Степень повреждения насаждений низовыми пожарами устанавливается по специальным шкалам, которые основаны на оценке среднего диаметра древостоя и средней высоты нагара на стволах деревьев (табл. 2, 3).

Послепожарный отпад в лесных фитоценозах, подверженных влиянию почвенных пожаров, находится в непосредственной зависимости от глубины прогорания органических горизонтов почвы, а также от степени повреждения (обгорания) корневой системы деревьев. Установлено, что в наибольшей степени почвенными пожарами повреждаются еловые древостои. При незначительной (до 5 см) глубине прогорания органического горизонта почвы послепожарный отпад в ельниках по числу стволов составляет 20-25 \%. При глубине прогорания органического горизонта почвы свыше 15 см в насаждениях ели большинство деревьев уже теряет жизнеспособность и их отпад составляет более $50 \%$. В то же время в сосняках послепожарный отпад по числу стволов свыше 50 \% наблюдается при глубине прогорания органических горизонтов почвы более $25 \mathrm{~cm}$.

Степень повреждения насаждений почвенными пожарами определяется по специальным шкалам, которые основываются на глубине прогорания органических горизонтов почвы и степени повреждения корневой системы деревьев (табл. 4). 
Т а б л и ц а 1. Минимальная высота нагара на стволах, при которой деревья в насаждениях основных лесообразующих пород теряют жизнеспособность

$\mathrm{T}$ a $\mathrm{b}$ le 1 . The minimum height of deposit on trunks with which trees in plantations of the main forest forming breeds lose viability

\begin{tabular}{|c|c|c|c|c|}
\hline \multirow{2}{*}{ Диаметр ствола (см) на высоте 1,3 м } & \multicolumn{4}{|c|}{ Минимальная высота нагара, м } \\
\cline { 2 - 5 } & Сосна & Ель & Береза & Ольха черная \\
\hline 6 & 0,6 & 0,3 & 0,7 & 0,9 \\
8 & 1,0 & 0,5 & 1,5 & 1,7 \\
10 & 2,0 & 0,8 & 1,7 & 1,9 \\
12 & 2,2 & 1,0 & 1,9 & 3,0 \\
14 & 2,4 & 1,2 & 2,8 & 3,2 \\
16 & 2,6 & 1,5 & 3,0 & 4,0 \\
18 & 3,0 & 1,7 & 3,5 & 4,5 \\
20 & 3,3 & 1,8 & 4,2 & 5,1 \\
22 & 3,5 & 1,9 & 4,5 & 5,1 \\
24 & 3,8 & 2,0 & 4,8 & 5,1 \\
26 & 4,0 & 2,0 & 5,1 & 5,1 \\
28 & 4,2 & 2,0 & 5,1 & 5,1 \\
30 & 4,8 & 2,2 & 5,1 & 5,1 \\
32 & 5,0 & 2,2 & 5,1 & 5,1 \\
34 & 5,0 & 2,5 & 5,1 & 5,1 \\
36 & 5,0 & 2,5 & 5,1 & 5,1 \\
38 & 5,0 & 2,5 & 5,1 & 5,1 \\
40 & 5,0 & 2,5 & 5,1 & 5,1 \\
\hline
\end{tabular}

Диагностика послепожарного состояния насаждений является основой для проведения, в зависимости от степени повреждения, первоочередных мероприятий по ведению хозяйства в начальный послепожарный период (своевременных санитарных рубок, позволяющих рационально использовать древесину нежизнеспособных, сильно поврежденных огнем деревьев; повышения густоты залесения площади расстроенных пожарами древостоев; содействия естественному возобновлению леса или создания лесных культур; восстановления утраченного после пожара почвенного плодородия), направленных на минимизацию последствий пожаров, предотвращение

Т а б л и ц а 2. Шкала определения степени повреждения хвойных насаждений низовыми пожарами

$\mathrm{T}$ a b 1 e 2. Scale of identification of damage rate of coniferous plantations by the ground fires

\begin{tabular}{|c|c|c|c|c|c|c|c|c|c|c|c|c|c|c|c|c|c|c|}
\hline \multirow{2}{*}{$\begin{array}{c}\text { Средняя высота } \\
\text { нагара, м }\end{array}$} & \multicolumn{18}{|c|}{ Степень повреждения при среднем диаметре древостоя, см } \\
\hline & 6 & 8 & 10 & 12 & 14 & 16 & 18 & 20 & 22 & 24 & 26 & 28 & 30 & 32 & 34 & 36 & 38 & 40 \\
\hline \multirow{2}{*}{$0,1-0,5$} & $\underline{2}$ & $\underline{2}$ & 1 & $\underline{1}$ & 1 & $\underline{1}$ & $\underline{1}$ & 1 & $\underline{1}$ & 1 & $\underline{1}$ & 1 & 1 & $\underline{1}$ & 1 & $\underline{1}$ & $\underline{1}$ & $\underline{1}$ \\
\hline & $\overline{4}$ & $\overline{3}$ & $\overline{3}$ & 2 & $\overline{1}$ & $\overline{1}$ & $\overline{1}$ & $\overline{1}$ & $\overline{1}$ & $\overline{1}$ & $\overline{1}$ & $\overline{1}$ & $\overline{1}$ & $\overline{1}$ & $\overline{1}$ & 1 & $\overline{1}$ & $\overline{1}$ \\
\hline \multirow{2}{*}{$0,6-1,0$} & $\underline{4}$ & $\underline{4}$ & $\underline{3}$ & 1 & 1 & 1 & 1 & 1 & 1 & 1 & 1 & $\underline{1}$ & 1 & 1 & 1 & 1 & 1 & 1 \\
\hline & $\overline{4}$ & $\overline{4}$ & $\overline{4}$ & $\overline{4}$ & $\overline{3}$ & $\overline{2}$ & 2 & $\overline{2}$ & $\overline{2}$ & $\overline{2}$ & 1 & $\overline{1}$ & $\overline{1}$ & $\overline{1}$ & $\overline{1}$ & 1 & 1 & 1 \\
\hline \multirow{2}{*}{$1,1-1,5$} & $\underline{4}$ & $\underline{4}$ & $\underline{4}$ & $\underline{3}$ & $\underline{2}$ & $\underline{2}$ & 1 & 1 & 1 & 1 & 1 & 1 & 1 & 1 & 1 & 1 & 1 & 1 \\
\hline & 4 & 4 & 4 & 4 & 4 & 4 & 3 & 3 & 3 & 3 & 3 & 2 & 2 & 2 & 2 & 2 & 2 & 2 \\
\hline \multirow{2}{*}{$1,6-2,0$} & $\underline{4}$ & $\underline{4}$ & $\underline{4}$ & $\underline{4}$ & $\underline{4}$ & $\underline{2}$ & $\underline{2}$ & $\underline{1}$ & $\underline{1}$ & 1 & $\underline{1}$ & $\underline{1}$ & 1 & $\underline{1}$ & 1 & $\underline{1}$ & $\underline{1}$ & $\underline{1}$ \\
\hline & $\overline{4}$ & $\overline{4}$ & $\overline{4}$ & $\overline{4}$ & $\overline{4}$ & $\overline{4}$ & $\overline{4}$ & $\overline{4}$ & $\overline{4}$ & $\overline{4}$ & 4 & 3 & 3 & 3 & 3 & 3 & 3 & 3 \\
\hline \multirow{2}{*}{$2,1-2,5$} & $\underline{4}$ & $\underline{4}$ & $\underline{4}$ & $\underline{4}$ & $\underline{4}$ & $\underline{4}$ & $\underline{3}$ & $\underline{2}$ & $\underline{2}$ & 1 & $\underline{1}$ & 1 & 1 & $\underline{1}$ & 1 & $\underline{1}$ & $\underline{1}$ & $\underline{1}$ \\
\hline & $\overline{4}$ & $\overline{4}$ & $\overline{4}$ & $\overline{4}$ & $\overline{4}$ & $\overline{4}$ & 4 & $\overline{4}$ & $\overline{4}$ & $\overline{4}$ & $\overline{4}$ & $\overline{4}$ & $\overline{4}$ & $\overline{3}$ & $\overline{3}$ & 3 & 3 & 3 \\
\hline \multirow{2}{*}{$2,6-3,0$} & $\underline{4}$ & $\underline{4}$ & $\underline{4}$ & $\underline{4}$ & $\underline{4}$ & $\underline{4}$ & $\underline{4}$ & $\underline{3}$ & $\underline{3}$ & $\underline{3}$ & $\underline{2}$ & 1 & 1 & 1 & $\underline{1}$ & 1 & $\underline{1}$ & $\underline{1}$ \\
\hline & 4 & 4 & 4 & 4 & 4 & 4 & 4 & 4 & 4 & 4 & 4 & 4 & 4 & 4 & 4 & 4 & 4 & 4 \\
\hline \multirow{2}{*}{$3,1-4,0$} & $\underline{4}$ & $\underline{4}$ & $\underline{4}$ & $\underline{4}$ & $\underline{4}$ & $\underline{4}$ & $\underline{4}$ & $\underline{4}$ & $\underline{4}$ & $\underline{4}$ & $\underline{3}$ & $\underline{3}$ & $\underline{3}$ & $\underline{2}$ & $\underline{2}$ & $\underline{2}$ & $\underline{2}$ & $\underline{2}$ \\
\hline & $\overline{4}$ & $\dot{4}$ & $\frac{\dot{4}}{4}$ & 4 & $\dot{4}$ & $\overline{4}$ & $\dot{4}$ & $\overline{4}$ & $\overline{4}$ & $\overline{4}$ & 4 & 4 & 4 & 4 & 4 & 4 & 4 & 4 \\
\hline \multirow{2}{*}{$4,1-5,0$} & $\underline{4}$ & $\underline{4}$ & $\underline{4}$ & $\underline{4}$ & $\underline{4}$ & $\underline{4}$ & $\underline{4}$ & $\underline{4}$ & $\underline{4}$ & $\underline{4}$ & $\underline{4}$ & $\underline{4}$ & $\underline{4}$ & $\underline{3}$ & $\underline{3}$ & $\underline{3}$ & $\underline{3}$ & $\underline{3}$ \\
\hline & $\overline{4}$ & $\overline{4}$ & $\overline{4}$ & 4 & $\overline{4}$ & $\overline{4}$ & $\overline{4}$ & $\overline{4}$ & $\overline{4}$ & $\overline{4}$ & $\overline{4}$ & $\overline{4}$ & $\overline{4}$ & $\overline{4}$ & $\overline{4}$ & $\overline{4}$ & $\overline{4}$ & $\overline{4}$ \\
\hline \multirow{2}{*}{5,1 и более } & $\underline{4}$ & $\underline{4}$ & $\underline{4}$ & $\underline{4}$ & $\underline{4}$ & $\underline{4}$ & $\underline{4}$ & $\underline{4}$ & $\underline{4}$ & $\underline{4}$ & $\underline{4}$ & $\underline{4}$ & $\underline{4}$ & $\underline{4}$ & $\underline{4}$ & $\underline{4}$ & $\underline{4}$ & $\underline{4}$ \\
\hline & 4 & 4 & 4 & 4 & 4 & 4 & 4 & 4 & 4 & 4 & 4 & 4 & 4 & 4 & 4 & 4 & 4 & 4 \\
\hline
\end{tabular}

П р и м е ч а н и е. В числителе указана степень повреждения сосны, в знаменателе - ели. 
Т а б л и ц а 3. Шкала определения степени повреждения березовых и черноольховых насаждений низовыми пожарами

$\mathrm{T}$ a $\mathrm{b} 1 \mathrm{e}$ 3. Scale of identification of damage rate in birch and black alder plantations from the ground fires

\begin{tabular}{|c|c|c|c|c|c|c|c|c|c|c|c|c|c|}
\hline \multirow{2}{*}{ Средняя высота нагара, м } & \multicolumn{13}{|c|}{ Степень повреждения при среднем диаметре древостоя, см } \\
\hline & 6 & 8 & 10 & 12 & 14 & 16 & 18 & 20 & 22 & 24 & 26 & 28 & 30 \\
\hline \multirow{2}{*}{$0,1-0,5$} & $\underline{4}$ & $\underline{3}$ & $\underline{2}$ & $\underline{1}$ & $\underline{1}$ & $\underline{1}$ & 1 & 1 & 1 & 1 & 1 & 1 & 1 \\
\hline & 3 & 2 & 2 & 1 & 1 & 1 & 1 & 1 & 1 & 1 & 1 & 1 & 1 \\
\hline \multirow{2}{*}{$0,6-1,0$} & $\underline{4}$ & $\underline{4}$ & $\underline{4}$ & $\underline{3}$ & $\underline{3}$ & $\underline{2}$ & $\underline{1}$ & $\underline{1}$ & 1 & $\underline{1}$ & $\underline{1}$ & $\underline{1}$ & $\underline{1}$ \\
\hline & 4 & 3 & 3 & 3 & 2 & 2 & 1 & 1 & 1 & 1 & 1 & 1 & 1 \\
\hline \multirow{2}{*}{$1,1-1,5$} & $\underline{4}$ & 4 & 4 & $\underline{4}$ & $\underline{3}$ & $\underline{3}$ & $\underline{2}$ & $\underline{2}$ & $\underline{2}$ & $\underline{2}$ & 1 & 1 & $\underline{1}$ \\
\hline & 4 & 4 & 4 & 3 & 3 & 2 & 2 & 2 & 1 & 1 & 1 & 1 & 1 \\
\hline \multirow{2}{*}{$1,6-2,0$} & $\underline{4}$ & $\underline{4}$ & $\underline{4}$ & $\underline{4}$ & $\underline{3}$ & $\underline{3}$ & $\underline{3}$ & $\underline{3}$ & $\underline{2}$ & $\underline{2}$ & $\underline{2}$ & $\underline{2}$ & $\underline{2}$ \\
\hline & 4 & 4 & 4 & 4 & 3 & 3 & 3 & 3 & 2 & 2 & 2 & 1 & 1 \\
\hline \multirow{2}{*}{$2,1-2,5$} & $\underline{4}$ & $\underline{4}$ & $\underline{4}$ & $\underline{4}$ & $\underline{4}$ & $\underline{4}$ & $\underline{3}$ & $\underline{3}$ & $\underline{3}$ & $\underline{3}$ & $\underline{3}$ & $\underline{2}$ & $\underline{2}$ \\
\hline & $\overline{4}$ & $\overline{4}$ & $\overline{4}$ & $\overline{4}$ & $\overline{4}$ & $\overline{3}$ & $\overline{3}$ & $\overline{3}$ & $\overline{3}$ & 3 & $\overline{2}$ & 2 & 2 \\
\hline \multirow{2}{*}{$2,6-3,0$} & 4 & 4 & 4 & 4 & 4 & 4 & 4 & $\underline{3}$ & $\underline{3}$ & $\underline{3}$ & $\underline{3}$ & $\underline{3}$ & $\underline{3}$ \\
\hline & 4 & 4 & 4 & 4 & 4 & 4 & 4 & 3 & 3 & 3 & 3 & 3 & 2 \\
\hline \multirow{2}{*}{$3,1-4,0$} & $\underline{4}$ & $\underline{4}$ & $\underline{4}$ & $\underline{4}$ & $\underline{4}$ & $\underline{4}$ & $\underline{4}$ & $\underline{4}$ & $\underline{4}$ & $\underline{3}$ & $\underline{3}$ & $\underline{3}$ & $\underline{3}$ \\
\hline & 4 & 4 & 4 & 4 & 4 & 4 & 4 & 4 & 3 & 3 & 3 & 3 & 3 \\
\hline \multirow{2}{*}{$4,1-5,0$} & $\underline{4}$ & $\underline{4}$ & $\underline{4}$ & $\underline{4}$ & $\underline{4}$ & $\underline{4}$ & $\underline{4}$ & $\underline{4}$ & $\underline{4}$ & $\underline{4}$ & $\underline{4}$ & $\underline{4}$ & $\underline{4}$ \\
\hline & $\overline{4}$ & $\overline{4}$ & $\overline{4}$ & $\overline{4}$ & $\overline{4}$ & $\overline{4}$ & $\overline{4}$ & $\overline{4}$ & $\overline{4}$ & $\overline{4}$ & $\overline{4}$ & $\overline{4}$ & 3 \\
\hline \multirow{2}{*}{5,1 и более } & $\underline{4}$ & $\underline{4}$ & 4 & 4 & 4 & 4 & 4 & 4 & 4 & 4 & 4 & 4 & $\underline{4}$ \\
\hline & 4 & 4 & 4 & 4 & 4 & 4 & 4 & 4 & 4 & $\overline{4}$ & 4 & $\overline{4}$ & 4 \\
\hline
\end{tabular}

П р и м е ч а н и е. В числителе указана степень повреждения березы, в знаменателе - ольхи черной.

возможного увеличения ущерба, а также на повышение продуктивности поврежденных древостоев, которые осуществляются в соответствии с Практическими рекомендациями по диагностике послепожарного состояния насаждений основных лесообразующих пород и ведению в них хозяйства [21].

Одной из основных динамических характеристик продуктивности и роста лесных фитоценозов, отражающих влияние на них различных природных и антропогенных факторов, в том числе

Т а б л и ц а 4. Шкала определения степени повреждения хвойных,

березовых и черноольховых насаждений почвенными пожарами

$\mathrm{T}$ a $\mathrm{b} 1$ e 4 . Scale of identification of damage rate in coniferous, birch and black alder plantations from the soil fires

\begin{tabular}{|c|c|c|c|}
\hline $\begin{array}{c}\text { Степень повреждения } \\
\text { древостоя }\end{array}$ & $\begin{array}{c}\text { Глубина прогорания органических } \\
\text { горизонтов почвы, см }\end{array}$ & $\begin{array}{c}\text { Степень повреждения (обгорания) } \\
\text { корневой системы деревьев, \% }\end{array}$ & $\begin{array}{c}\text { Послепожарный отпад } \\
\text { по числу деревьев, \% }\end{array}$ \\
\hline \multicolumn{4}{|c|}{ Хвойные насаждения } \\
\hline $\begin{array}{c}\mathrm{I} \\
\text { (слабая) }\end{array}$ & $\leq 5$ & $\frac{-}{5-10}$ & $\frac{10-15}{20-25}$ \\
\hline $\begin{array}{c}\text { II } \\
\text { (средняя) }\end{array}$ & $6-15$ & $\frac{10-15}{15-30}$ & $\frac{16-30}{26-50}$ \\
\hline $\begin{array}{c}\text { III } \\
\text { (сильная) }\end{array}$ & $16-25$ & $\frac{25-40}{40-70}$ & $\frac{31-50}{51-80}$ \\
\hline $\begin{array}{c}\text { IV } \\
\text { (очень сильная) }\end{array}$ & $>25$ & $\frac{50-85}{80-95}$ & $\frac{51-95}{81-100}$ \\
\hline \multicolumn{4}{|c|}{ Березовые и черноольховые насаждения } \\
\hline $\begin{array}{c}1 \\
\text { (слабая) }\end{array}$ & $\leq 5$ & - & $\begin{array}{l}\leq 15 \\
\leq 10\end{array}$ \\
\hline $\begin{array}{c}\text { II } \\
\text { (средняя) }\end{array}$ & $6-15$ & $10-20$ & $\frac{16-40}{11-35}$ \\
\hline $\begin{array}{c}\text { III } \\
\text { (сильная) }\end{array}$ & $16-25$ & $21-30$ & $\frac{41-50}{36-50}$ \\
\hline $\begin{array}{c}\text { IV } \\
\text { (очень сильная) }\end{array}$ & $>25$ & $>30$ & $>50$ \\
\hline
\end{tabular}

П р и м е ч а н и е. В числителе указана степень повреждения корневых систем деревьев в сосняках, в знаменателе - в ельниках. 
и пирогенного воздействия, является радиальный прирост древесных пород. Исследование динамики среднепериодического радиального прироста в хвойных насаждениях, пройденных низовыми пожарами средней и сильной интенсивности, свидетельствует о том, что в течение первых 5 послепожарных лет наблюдается достоверное снижение по сравнению с допожарным периодом (контроль) радиального прироста деревьев с различными ступенями их толщины (табл. 5).

Т а б л и ц а 5. Влияние низовых пожаров на среднепериодический прирост по диаметру деревьев с различными ступенями их толщины в хвойных насаждениях

$\mathrm{T}$ a $\mathrm{b} l \mathrm{e}$. Influence of the ground fires on average gain in diameter of trees of various steps of thickness in coniferous plantations

\begin{tabular}{|c|c|c|c|c|c|c|}
\hline \multirow[b]{3}{*}{$\begin{array}{c}\text { Ступень } \\
\text { толщины }\end{array}$} & \multicolumn{6}{|c|}{ Среднепериодический прирост по диаметру, мм } \\
\hline & \multicolumn{3}{|c|}{ Пройденные пожарами насаждения } & \multicolumn{3}{|c|}{ Не пройденные пожарами насаждения (контроль) } \\
\hline & $\begin{array}{c}\text { послепожарный } \\
\text { период }\end{array}$ & $\begin{array}{c}\text { допожарный } \\
\text { период }\end{array}$ & $\begin{array}{c}\text { в процентах } \\
\text { по отношению } \\
\text { к допожарному периоду }\end{array}$ & $\begin{array}{c}\text { соответствующий } \\
\text { послепожарный } \\
\text { период }\end{array}$ & $\begin{array}{c}\text { соответствующий } \\
\text { допожарный } \\
\text { период }\end{array}$ & $\begin{array}{c}\text { в процентах } \\
\text { по отношению } \\
\text { к соответствующему } \\
\text { допожарному периоду }\end{array}$ \\
\hline \multicolumn{7}{|c|}{ Сосновые насаждения } \\
\hline 8 & 0,96 & 1,36 & 70,6 & 1,32 & 1,38 & 95,6 \\
\hline 16 & 1,22 & 1,92 & 63,5 & 1,94 & 1,90 & 96,1 \\
\hline 20 & 1,07 & 1,19 & 89,9 & 1,17 & 1,23 & 95,1 \\
\hline 24 & 1,73 & 1,96 & 88,3 & 2,00 & 2,00 & 100,0 \\
\hline 28 & 1,45 & 1,82 & 79,7 & 1,67 & 1,64 & 101,8 \\
\hline 32 & 1,78 & 1,91 & 93,2 & 1,85 & 1,90 & 97,4 \\
\hline \multicolumn{7}{|c|}{ Еловые насаждения } \\
\hline 8 & 1,42 & 1,88 & 75,5 & 1,75 & 1,86 & 94,1 \\
\hline 16 & 1,61 & 1,89 & 81,3 & 2,01 & 2,06 & 97,6 \\
\hline 20 & 2,16 & 2,46 & 87,8 & 2,35 & 2,53 & 92,9 \\
\hline 28 & 2,48 & 3,00 & 82,7 & 2,85 & 3,05 & 93,4 \\
\hline
\end{tabular}

Установлено, что в пройденных низовыми пожарами средней и сильной интенсивности сосновых насаждениях в течение первых 5 лет после пожара наблюдается снижение среднепериодического радиального прироста деревьев с различными ступенями их толщины до 36,5 \%, в еловых древостоях - до 24,5 \% по сравнению с соответствующим допожарным периодом.

Как показали результаты исследований, основными диагностическими критериями пожароустойчивости сосновых, еловых, березовых и черноольховых насаждений являются: тип условий местопроизрастания, средний диаметр древостоя, доля лиственных пород в его составе, количество подроста хвойных пород, запас лесных горючих материалов наземной группы. На основании этих критериев разработана шкала оценки пожароустойчивости насаждений основных лесообразующих пород Беларуси (табл. 6).

Выбор метода создания и формирования пожароустойчивых насаждений естественного и искусственного происхождения определяется типом лесорастительных условий, возрастом древостоя, зоной антропогенной нагрузки и осуществляется путем регулирования доли лиственных пород в составе хвойных насаждений при их создании и проведении рубок ухода, количества подроста хвойных пород, а также создания противопожарных разрывов и заслонов, формирования пожароустойчивых опушек, очистки мест рубок и ликвидации захламленности.

Выполненный на протяжении последнего десятилетия анализ распределения площади гарей в лесном фонде Беларуси свидетельствует о том, что 88,3 \% от общей площади гарей образуется в сосновых, $6,7 \%$ - в березовых, $2,7 \%$ - в еловых, $1,8 \%$ - в черноольховых насаждениях. В других лесных формациях долевое участие гарей составляет около $0,5 \%$ от их общей площади. Наиболее значительная часть (46,7 \% от общей площади) гарей образуется в наиболее распространенных и пожароопасных в лесном фонде сосняках мшистых и вересковых.

Выполнена оценка успешности естественного возобновления хозяйственно ценных древесных пород на гарях в различных условиях местопроизрастания (табл. 7).

Лесовосстановление на гарях насаждений основных лесообразующих пород в лесном фонде страны осуществляется на регионально-типологической основе в зависимости от лесорастительных 
Т а б л и ц а 6. Шкала оценки пожароустойчивости насаждений основных лесообразующих пород Беларуси

$\mathrm{T} \mathrm{a}$ b 1 e 6 . Scale of assessment of fire resistance of plantations of the main forest forming breeds of Belarus

\begin{tabular}{|c|c|c|c|c|c|c|c|}
\hline \multirow[b]{2}{*}{$\begin{array}{l}\text { Класс пожа- } \\
\text { роустойчиво- } \\
\text { сти / балл }\end{array}$} & \multirow[b]{2}{*}{ Порода } & \multicolumn{5}{|c|}{ Факторы пожароустойчивости насаждений } & \multirow[b]{2}{*}{$\begin{array}{c}\text { Ожидаемый } \\
\text { послепожарный } \\
\text { отпад } \\
\text { по запасу, \% }\end{array}$} \\
\hline & & $\begin{array}{c}\text { Тип условий } \\
\text { местопроизраста- } \\
\text { ния }\end{array}$ & $\begin{array}{l}\text { Средний } \\
\text { диаметр } \\
\text { ствола, } \\
\text { см } \\
\end{array}$ & $\begin{array}{c}\text { Доля лиственных } \\
\text { пород в составе } \\
\text { насаждений, \% }\end{array}$ & $\begin{array}{c}\text { Запас лесных горючих } \\
\text { материалов наземной } \\
\text { группы в абсолютно } \\
\text { сухом состоянии, т/га } \\
\end{array}$ & $\begin{array}{c}\text { Густота подро- } \\
\text { ста хвойных } \\
\text { пород, тыс. шт/га }\end{array}$ & \\
\hline \multirow{3}{*}{$\frac{\text { Высокий }}{3}$} & Сосна & $\mathrm{A}_{4}, \mathrm{~A}_{5}, \mathrm{~B}_{4}, \mathrm{C}_{2}$ & $>22$ & \multirow{2}{*}{$40-50$} & $<10$ & \multirow{2}{*}{ Редкий (<2) } & \multirow{3}{*}{$<20$} \\
\hline & Ель & $\mathrm{C}_{2}, \mathrm{C}_{3}, \mathrm{C}_{4}, \mathrm{Z}_{2}, \mathrm{Z}_{3}$ & $>26$ & & $<20$ & & \\
\hline & $\begin{array}{l}\text { Береза, } \\
\text { ольха черная }\end{array}$ & $Д_{2}, Д_{3}, Д_{4}, C_{4-5}$ & $>18$ & - & $<15$ & - & \\
\hline \multirow{3}{*}{$\frac{\text { Средний }}{2}$} & Сосна & $\mathrm{A}_{3}, \mathrm{~B}_{2}, \mathrm{~B}_{3}$ & $12-22$ & $20-30$ & $10-25$ & Средн & \multirow{3}{*}{$20-50$} \\
\hline & Ель & $\mathrm{B}_{4}, \mathrm{~B}_{5}$ & $18-26$ & $20-30$ & $20-35$ & густоты (2-8) & \\
\hline & $\begin{array}{l}\text { Береза, } \\
\text { ольха черная }\end{array}$ & $\mathrm{A}_{2}, \mathrm{~B}_{4}, \mathrm{~B}_{5}, \mathrm{C}_{3}, \mathrm{C}_{4}$ & $8-18$ & - & $15-25$ & - & \\
\hline \multirow{3}{*}{$\frac{\text { Низкий }}{1}$} & Сосна & $\mathrm{A}_{1}, \mathrm{~A}_{2}$ & $<12$ & & $>25$ & \multirow{2}{*}{$\begin{array}{c}\text { Густой, } \\
\text { очень густой } \\
(>8) \\
\end{array}$} & \multirow{3}{*}{50 и более } \\
\hline & Ель & $\mathrm{B}_{2}$ & $<18$ & 10 и менее & $>35$ & & \\
\hline & $\begin{array}{l}\text { Береза, } \\
\text { ольха черная }\end{array}$ & $\mathrm{A}_{2}, \mathrm{~B}_{2}$ & $<8$ & - & $>25$ & - & \\
\hline
\end{tabular}

Т а б л и ц а 7. Методы лесовосстановления на гарях насаждений основных лесообразующих пород

$\mathrm{T}$ a b 1 e 7 . Reforestation methods on burnt-out places in plantations of the main forest forming breeds

\begin{tabular}{|l|c|c|c|c|}
\hline \multirow{2}{*}{$\begin{array}{c}\text { Тип условий } \\
\text { местопроизрастания }\end{array}$} & \multicolumn{4}{|c|}{ Методы лесовосстановления } \\
\cline { 2 - 3 } & Искусственное лесовосстановление & $\begin{array}{c}\text { Естественное } \\
\text { возобновление леса }\end{array}$ & $\begin{array}{c}\text { Комбинированный } \\
\text { метод }\end{array}$ \\
\cline { 2 - 4 } & посадка & посев & - & - \\
$\mathrm{A}_{1}$ & + & - & + & + \\
$\mathrm{A}_{2} \mathrm{~A}_{3}, \mathrm{~B}_{2}, \mathrm{~B}_{3}$ & + & + & + & + \\
$\mathrm{C}_{3}, Д_{3}$ & + & - & + & - \\
$\mathrm{A}_{4}, \mathrm{~B}_{4}$ & - & - & + & - \\
$\mathrm{C}_{4}, \mathrm{C}_{5}, Д_{4}$ & - & - & & + \\
\hline
\end{tabular}

условий и послепожарного состояния плодородия почвы, лесоводственно-биологических особенностей культивируемых древесных и кустарниковых пород, целей лесовыращивания, а также в соответствии с разработанными Рекомендациями по лесовосстановлению на гарях в лесном фонде Республики Беларусь [22].

Для эффективной организации противопожарной профилактики и борьбы с лесными пожарами с целью минимизации их площади и негативных последствий необходимо разделение лесного фонда на однородные по целому комплексу природно-климатических, лесорастительных, лесопирологических, экономических и ряду других факторов территории, которые в своей совокупности определяют необходимость проведения одинаковых видов и объемов противопожарных мероприятий с аналогичными затратами сил и средств на их реализацию.

В основу разработанного впервые лесопожарного районирования территории Беларуси положен комплексный показатель потенциальной опасности возникновения и распространения лесных пожаров, включающий класс природной пожарной опасности лесов, уровень горимости лесов, плотность населения, лесистость региона, распределение лесного фонда юридических лиц, ведущих лесное хозяйство, по зонам радиоактивного загрязнения:

$$
\mathrm{K}_{\text {п.о }}=0,4 \mathrm{~K}+0,4 Л+0,1 \Gamma+0,1 \Pi+\mathrm{T},
$$

где $\mathrm{K}_{\text {п.о }}$ - класс природной пожарной опасности лесного фонда юридических лиц, ведущих лесное хозяйство; Л - лесистость территории лесного фонда; Г - горимость лесов; П - плотность населения региона; Т - степень тяжести радиоактивного загрязнения территории лесного фонда.

На основании величины комплексного показателя потенциальной опасности возникновения и распространения лесных пожаров территория Беларуси разделена на три лесопожарных пояса, 


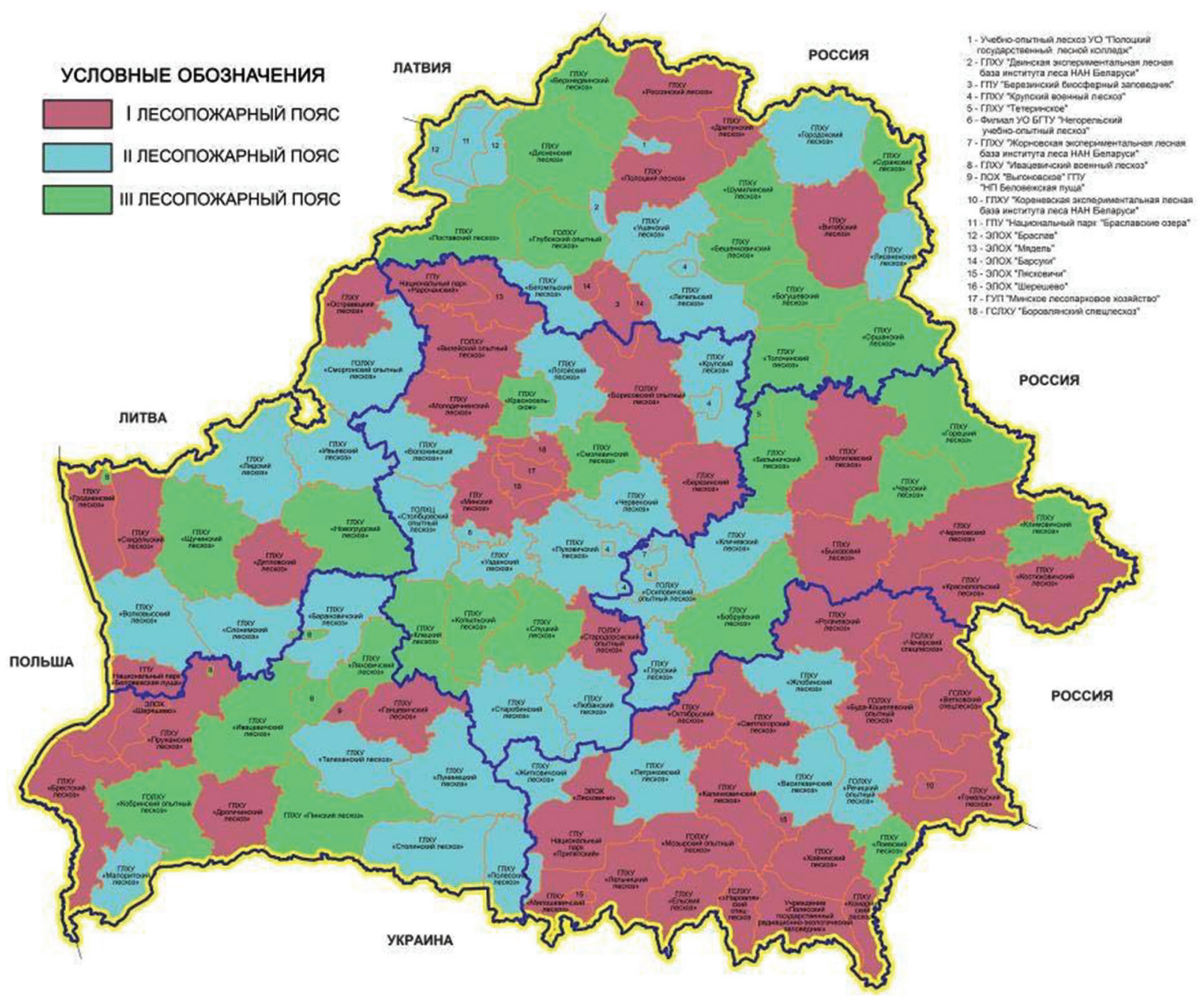

Рис. 3. Карта лесопожарного районирования территории Беларуси

Fig. 3. Card of forest fire division into districts of the territory of Belarus

для которых дифференцированы виды и объемы мероприятий по противопожарному обустройству расположенного на них лесного фонда юридических лиц, ведущих лесное хозяйство (рис. 3).

Дифференцированная система противопожарных мероприятий в лесном фонде, разработанная на основе лесопожарного районирования, включает создание в лесах системы противопожарных барьеров в виде заслонов и разрывов, минерализованных защитных полос, ограничивающих распространение пожаров, а также устройство сети дорог и пожарных водоемов для обеспечения оперативной ликвидации очагов горения и является одним из основополагающих технических нормативных правовых актов по охране лесов от пожаров в Беларуси (СТБ 1582-2005 «Устойчивое лесоуправление и лесопользование. Требования к мероприятиям по охране леса» [23] и ТКП 1932009 «Правила противопожарного обустройства лесов Республики Беларусь» [24]).

Заключение. В природно-климатических и лесорастительных условиях Беларуси в насаждениях основных лесообразующих пород степень их повреждения пирогенным фактором является главным критерием для оценки их состояния и назначения необходимых мероприятий по повышению продуктивности лесных фитоценозов и минимизации в них негативных последствий пожаров. Установлены зависимости величины послепожарного отпада деревьев по числу стволов и запасу древесины в сосновых, еловых, березовых и черноольховых насаждениях от вида и интенсивности пожара.

Разработаны специальные шкалы для оценки степени повреждения пирогенным фактором насаждений основных лесообразующих пород, которые при низовых пожарах основаны на определении среднего диаметра древостоя и средней высоты нагара на стволах, при почвенных - 
на оценке глубины прогорания органических горизонтов почвы и степени повреждения корневых систем деревьев пожарах. В поврежденных низовыми пожарами средней и сильной интенсивности сосновых насаждениях в течение первых 5 лет после пожара наблюдается снижение среднепериодического радиального прироста деревьев с различными ступенями их толщины до $36,5 \%$, в еловых древостоях - до 24,5 \% по сравнению с соответствующим допожарным периодом. Установлено, что основными диагностическими критериями пожароустойчивости насаждений являются: тип условий местопроизрастания, средний диаметр древостоя, доля в составе насаждения лиственных пород, количество подроста хвойных пород, запас лесных горючих материалов наземной группы. Данные критерии составили основу разработанной шкалы оценки пожароустойчивости насаждений основных лесообразующих пород.

Выбор метода лесовосстановления на гарях определяется количеством последующего естественного возобновления хозяйственно ценных пород и лесорастительными условиями. Применяемые в настоящее время разработанные нами технологии лесовосстановления на гарях на зонально-типологической основе позволяют создавать биологически устойчивые и высокопродуктивные насаждения в лесном хозяйстве страны.

Внедрение лесопожарного районирования территории Беларуси в практику противопожарного обустройства лесов позволило более обоснованно планировать и реализовывать оптимальные виды и объемы профилактических мероприятий по охране лесов от пожаров, что обеспечило минимизацию их площади и причиняемого материального и экологического ущерба.

\section{Список использованных источников}

1. Государственный лесной кадастр Республики Беларусь : по состоянию на 01.01.2017 г. / М-во лес. хоз-ва Респ. Беларусь, Лесоустр. респ. унитар. предприятие «Белгослес». - Минск : б. и., 2017. - 72 с.

2. Арцыбашев, Е. С. Влияние пожаров на лесные биогеоценозы / Е. С. Арцыбашев // Биосфера. - 2014. - Т. 6, № 1. C. $53-59$.

3. Демаков, Ю. П. Послепожарный отпад в сосняках и его прогнозирование / Ю. П. Демаков, К. К. Калинин, А. В. Иванов // Лес. хоз-во. - 1982. - № 6. - С. 51-53.

4. Заблоцкий, В. И. Стратегия повышения пожароустойчивости и снижения горимости ленточных боров Алтая / В. И. Заблоцкий, В. А. Черных, В. В. Фуряев // Лес. хоз-во. - 2003. - № 3. - С. 38-40.

5. Лесные пожары и их последствия : сб. ст. / отв. ред. Н. П. Курбатский. - Красноярск : Ин-т леса и древесины Сибир. отд-ния Акад. наук СССР, 1985. - 138 с.

6. Санников, С. Н. Пожары как фактор трансформации, возобновления, стабильности и эволюции сосновых лесов Северной Евразии / С. Н. Санников // Охрана лесов от пожаров в современных условиях : материалы Междунар. науч.-практ. конф., Хабаровск, 27-29 марта 2002 г. / редкол. : М. А. Шешуков [и др.]. - Хабаровск, 2002. - С 310-315.

7. Усеня, В. В. Современные методы и средства охраны лесов от пожаров и ликвидации их последствий в Республике Беларусь / В. В. Усеня // Проблемы лесоведения и лесоводства : сб. науч. тр. / Ин-т леса НАН Беларуси. - Гомель, 2015. - Вып. 75. - С. 596-610.

8. Усеня, В. В. Лесные пожары, последствия и борьба с ними / В. В. Усеня. - Гомель : Ин-т леса НАН Беларуси, 2002. $-206 \mathrm{c}$.

9. Усеня, В. В. Продуктивность и восстановление лесных фитоценозов после пожаров / В. В. Усеня, Е. Н. Каткова. Минск : Белорус. наука, 2010. - 247 с.

10. Фуряев, В. В. Пожароустойчивость сосновых лесов / В. В. Фуряев, В. И. Заблоцкий, В. А. Черных. - Новосибирск : Наука, 2005. - 159 с.

11. Цветков, П. А. Пирогенные свойства древесных пород / П. А. Цветков // Лесоведение. - 2011. - № 2. - С. 25-31.

12. Ryan Kevin, C. Dynamic interactions between forest structure and fire behavior in boreal ecosystems / C. Ryan Kevin // Silva Fennica. - 2002. - Vol. 36, N 1. - P. 13-39. https://doi.org/10.14214/sf.548

13. Harmon, M. E. Survival of trees after low-intensity surface fires in Great Smoky Mountains National Park // Ecology. 1984. - Vol. 65, N 3. - P. 796-802. https://doi.org/10.2307/1938052

14. Davis, K. P. Forest fire: control and use / K. P. Davis, G. M. Byram, W. R. Krumm. - New York : McGrau-Hill, 1959. $584 \mathrm{p}$.

15. Fire-caused tree mortality in thinned Douglass-fir stands in Patogonia, Argentina / M. M. Godoy [et al.] // Int. J. Wildland Fire. - 2013. - Vol. 22, N 6. - P. 810-814. https://doi.org/10.1071/wf12107

16. Юркевич, И. Д. География, типология и районирование лесной растительности / И. Д. Юркевич, В. С. Гельтман. - Минск : Наука и техника, 1965. - 288 с.

17. Юркевич, И. Д. Выделение типов леса при лесоустроительных работах / И. Д. Юркевич. - 3-е изд., доп. Минск : Наука и техника, 1980. - 120 с.

18. Справочник таксатора / В. С. Мирошников [и др.] ; под общ. ред. В. С. Мирошникова. - 2-е изд., перераб. и доп. - Минск : Ураджай, 1980. - 360 с.

19. Доспехов, Б. А. Методика полевого опыта / Б. А. Доспехов. - М. : Колос, 1965. -423 с.

20. ТКП 026-2006 (02080) «Санитарные правила в лесах Республики Беларусь». - Минск : б. и., 2006. - 42 с. 
21. Практические рекомендации по диагностике послепожарного состояния насаждений основных лесообразующих пород и ведению в них хозяйства // Научно-техническая информация в лесном хозяйстве / М-во лес. хоз-ва Респ. Беларусь, Респ. унитар. предприятие «Белгипролес». - Минск, 2005. - Вып. 5. - С. 5-21.

22. Рекомендации по лесовосстановлению на гарях в лесном фонде Беларуси. - Минск : М-во лес. хоз-ва Респ. Беларусь, 2010. - 9 с.

23. СТБ 1582-2005 «Устойчивое лесоуправление и лесопользование. Требования к мероприятиям по охране леса». - Минск : Госстандарт, 2006. - 10 с.

24. ТКП 193-2009 (02080) «Правила противопожарного обустройства лесов Республики Беларусь». - Минск : б. и., 2009. -12 с.

\section{References}

1. The state forest inventory of the Republic of Belarus as of 01.01.2017. Minsk, 2017. 72 p. (in Russian).

2. Artsybashev E. S. Influence of fires on forest biogeocenoses. Biosfera [Biosphere], 2014, vol. 6, no. 1, pp. 53-59 (in Russian).

3. Demakov Yu. P., Kalinin K. K., Ivanov A. V. Postfire falling-off in pine forests and its forecasting. Lesnoe khozyaistvo [Forestry], 1982, no. 6, pp. 51-53 (in Russian).

4. Zablotskii V. I., Chernykh V. A., Furyaev V. V. Strategy of increase in fire resistance and decrease in inflammability of tape pine forests of Altai. Lesnoe khozyaistvo [Forestry], 2003, no. 3, pp. 36-38 (in Russian).

5. Kurbatskii N. P. (ed.). Wildfires and their consequences. Krasnoyarsk, Institute of Forestry and Wood of the Siberian branch of the Academy of Sciences of the USSR, 1985. 138 p. (in Russian).

6. Sannikov S. N. Fires as a factor of transformation, renewal, stability and evolution of pine forests of Northern Eurasia. Okhrana lesov ot pozharov $v$ sovremennykh usloviyakh: materialy Mezhdunarodnoi nauchno-prakticheskoi konferentsii (Khabarovsk, 27-29 marta 2002 g.) [The present forest fire protection: materials of the International scientific and practical conference (Khabarovsk, March 27-29, 2002)]. Khabarovsk, 2002, pp. 310-315 (in Russian).

7. Usenya V. V. Modern methods and means of forest prevention from fires and elimination of their consequences in the Republic of Belarus. Problemy lesovedeniya i lesovodstva: sbornik nauchnykh trudov Instituta lesa Natsional'noi akademii nauk Belarusi [Problems of forest science and forestry: a collection of scientific works of the Forest Institute of the National Academy of Sciences of Belarus]. Gomel, 2015, iss. 75, pp. 596-610 (in Russian).

8. Usenya V. V. Wildfires, consequences and fight against them. Gomel, Institute of Forest of the National Academy of Sciences of Belarus, 2002. 206 p. (in Russian).

9. Usenya V. V., Katkova E. N. Productivity and restoration of forest phytocenoses after fires. Minsk, Belaruskaya navuka Publ., 2010. 247 p. (in Russian).

10. Furyaev V. V., Zablotskii V. I., Chernykh V. A. Fire resistance of pine forests. Novosibirsk, Nauka Publ., 2005. 159 p. (in Russian).

11. Tsvetkov P. A. Pyrogenetic properties of tree species. Lesovedeniye [Forest Science], 2011, no. 2, pp. 25-31 (in Russian).

12. Ryan Kevin C. Dynamic interactions between forest structure and fire behavior in boreal ecosystems. Silva Fennica, 2002, vol. 36, no. 1, pp. 13-39. https://doi.org/10.14214/sf.548

13. Harmon Mark E. Survival of trees after low-intensity surface fires in Great Smoky Mountains National Park. Ecology, 1984, vol. 85, no. 3, pp. 796-802. https://doi.org/10.2307/1938052

14. Davis K. P., Byram G. M., Krumm W. R. Forest fire: control and use. New York, McGrau-Hill, 1959. 584 p.

15. Godoy M. M., Defossé G. E., Bianchi L. O., Davel M. M., Withington T. E. Fire-caused tree mortality in thinned Douglass-fir stands in Patogonia, Argentina. International Journal of Wildland Fire, 2013, vol. 22, no. 6, pp. 810-814. https:// doi.org/10.1071/wf12107

16. Yurkevich I. D., Gel'tman V. S. Typology and division into districts of forest vegetation. Minsk, Nauka i tekhnika Publ., 1965. 288 p. (in Russian).

17. Yurkevich I. D. Allocation of types of forests during the forest management works (add. tab.). 3rd ed. Minsk, Nauka i tekhnika Publ., 1980. 120 p. (in Russian).

18. Miroshnikov V. S. (ed.). The reference book by the claimsman. 2nd ed. Minsk, Uradzhai Publ., 1980. 360 p. (in Russian).

19. Dospekhov B. A. Methogolodgy of field experiment. Moscow, Kolos Publ., 1965. 423 p. (in Russian).

20. TCP 026-2006 (02080) "Health regulations in forests of the Republic of Belarus". Minsk, 2006. 42 p. (in Russian).

21. Practical recommendations about diagnostics of a postfire condition of plantations of the main forest forming breeds and maintaining economy in them. Nauchno-tekhnicheskaya informatsiya v lesnom khozyaistve [Scientific and technical information in forestry]. Minsk, 2005, iss. 5, pp. 5-21 (in Russian).

22. Recommendations on reforestation on the burnt-out places in the forest fund of Belarus. Minsk, Ministry of Forestry of the Republic of Belarus, 2010.9 p. (in Russian).

23. STB 1582-2005 "Steady forest management and forest exploitation. Requirements to actions for forest protection". Minsk, Gosstandart Publ., 2006. 10 p. (in Russian).

24. TCP 193-2009 (02080) "Rules of fire-prevention arrangement of forests of the Republic of Belarus". Minsk, 2009.12 p. (in Russian).

\section{Информация об авторе}

Усеня Владимир Владимирович - член-корреспондент, д-р с.-х. наук, профессор, заместитель директора по научной работе. Институт леса НАН Беларуси (ул. Пролетарская, 71, 246001, г. Гомель, Республика Беларусь). E-mail: usenyaforinst@gmail.com

\section{Information about the author}

Vladimir V. Usenya - Corresponding Member, D. Sc. (Agricult.), Professor, Deputy director for scientific work. Institute of Forest of the National Academy of Sciences of Belarus (71, Proletarskaya St., 246001, Gomel, Republic of Belarus). E-mail: usenyaforinst@gmail.com 